\title{
Scientific Approach to Celebrate Festivals in Maharashtra in India - A Conceptual Study
}

\author{
Review article
}

\section{Manisha G Dunghav ${ }^{*}$}

1. Associate Professor, Department of Sanskrit Samhita and Siddhanta, DY Patil University, School of Ayurveda, Nerul, Navi Mumbai \begin{abstract}
follow rituals and beliefs on mythological stories. to desha (land).

\section{Introduction:}

India is known as the land of festivals which are no more confined to the boundaries of our nation but also being celebrated by the different communities around the world. So celebration of festival is the indivisible part of Indian people's life. Festival is the joint which brings together with loving bond. It is observed that sometimes some mythological stories and sometimes some atmospheric reasons are behind the celebration of festivals.
\end{abstract}

Abstract

Festival celebration is an inseparable event from the lifestyle of Indians. This study is proposed to explain the scientific approach towards the Indian festivals to promote good health and to overcome the wrong beliefs of mythological stories to particular festivals.

Indian culture is having great diversities in traditions and customs.It could be due to geographical distribution .Maharashtra also follow its own customs \& traditions and celebrate festivals for the acceptance of this environmental changes to mentain sound health rather than

So, while celebrating festivals one should follow the regimen of ritu sandhi according

Key Words: Festivals, Ayurveda seasonal regimen and festivals, Ayurveda and festivals, definite relation between festivals and principles of Ayurveda of seasonal regimen.

\footnotetext{
*Corresponding Author:

Manisha G Dunghav

Associate Professor

Department of Sanskrit Samhita \&

Siddhanta,

D.Y.Patil University, School of Ayurveda

Nerul, Navi Mumbai

Email Id-manisha.dunghav28@gmail.com
}

This study explains the relation between festivals and principal of Ayurveda of seasonal regimen.

\section{Aims and objectives:}

- To study the scientific approach of various festivals celebrated in Maharashtra.

- To explain the relation between festivals and seasonal regimen according to Ayurveda.

\section{Materials \& methods:}

Ayurveda texts like Brihattrayee, Laghutrayee were used which are related to seasonal regimen.

Various texts on festivals were used which was available.

\section{Conceptual study:}

According to Hindu and English calendar one year is divided into 12 months. According to Ayurveda one year 
is divided into six seasons. One season comprises of two months and also whole year is divided into two Ayana i.e. Uttarayana (the period when sun is seen traversing to the north of equation) and Dakshinayana (the period when the sun is seen traversing to the south of the equator). (1).

Uttarayana is also called as Adanakala (period of extraction). Adanakala takes away human strength day by day. Three consecutive seasons Shishira (Extreme winter), Vasanta (spring) and Grishma (summer) comprise Uttarayana. Dakshinayana is also called as Visargakala. (Period of discharge) .Visargakala gives back vitality and strength or body gains strength during this period.The seasons of Varsha (Rainy),
Sharada (Autumn) and Hemanta (Early winter) comprise Dakshinayana.

ADANAKALA: During this period, the sun is above the north of equator, the earth has decreased moisture content, and the air becomes dry. The atmosphere changes, affect human body causing a gradual decrease in vitality and strength. Since it takes away strength, the period is known as Adanakala (2).

VISARGAKALA : During this period sun is seen moving in southern direction from east to west and hence called Dakshinayana.

During this period, Sun is above the south of the equator. The earth is blessed with increase in the moisture content, the body will be supple and strong. Thus it is held that this period is Visarga Kala, as the sun "lets out" strength to the organism. (3)

Table No.1 Showing Seasons, Hindu Months, English Months, Festivals and Diet According To Seasons

\begin{tabular}{|c|c|c|c|c|}
\hline SEASONS & $\begin{array}{l}\text { HINDU } \\
\text { MONTHS }\end{array}$ & $\begin{array}{c}\text { ENGLISH } \\
\text { MONTHS }\end{array}$ & FESTIVALS & $\begin{array}{l}\text { TASTE OF DIET } \\
\text { ACCORDING } \\
\text { TO } \\
\text { SEASONS }\end{array}$ \\
\hline \multirow[t]{2}{*}{$\begin{array}{l}\text { Shishira } \\
\text { (Extreme } \\
\text { winter) }\end{array}$} & Magha & $\begin{array}{l}\text { Mid January- } \\
\text { Mid } \\
\text { February }\end{array}$ & \multirow[t]{2}{*}{$\begin{array}{l}\text { Mahashivaratri } \\
\text { Holi } \\
\text { Rangapanchami }\end{array}$} & \multirow[t]{2}{*}{$\begin{array}{l}\text { Madhura (Sweet) } \\
\text { Amla }(\text { Sour }) \\
\text { Lavana }(\text { Salt })\end{array}$} \\
\hline & Phalguna & $\begin{array}{l}\text { Mid } \\
\text { February- } \\
\text { Mid March }\end{array}$ & & \\
\hline \multirow[t]{2}{*}{$\begin{array}{l}\text { Vasanta } \\
\text { (Spring) }\end{array}$} & Chaitra & $\begin{array}{l}\text { Mid March- } \\
\text { Mid April }\end{array}$ & \multirow[t]{2}{*}{$\begin{array}{l}\text { Gudi Padwa, } \\
\text { Akshaya Tritiya }\end{array}$} & \multirow{2}{*}{$\begin{array}{l}\text { Katu (Pungent) } \\
\text { Tikta (Bitter) } \\
\text { Kashaya } \\
\text { (Astringent) }\end{array}$} \\
\hline & Vaishakha & $\begin{array}{l}\text { Mid April- } \\
\text { Mid May }\end{array}$ & & \\
\hline \multirow{2}{*}{$\begin{array}{l}\text { Grishma } \\
\text { (Summer) }\end{array}$} & Jyeshtha & $\begin{array}{l}\text { Mid May- } \\
\text { Mid June }\end{array}$ & \multirow[t]{2}{*}{ Vata Pournima } & \multirow[t]{2}{*}{ Madhura (Sweet) } \\
\hline & Ashadha & $\begin{array}{l}\text { Mid June- } \\
\text { Mid July }\end{array}$ & & \\
\hline \multirow[t]{2}{*}{$\begin{array}{l}\text { Varsha } \\
\text { (Rain) }\end{array}$} & Shravana & $\begin{array}{l}\text { Mid July- } \\
\text { Mid August }\end{array}$ & \multirow{2}{*}{$\begin{array}{l}\text { Naga Panchami } \\
\text { Gokulashtami } \\
\text { ShravanaPournima } \\
\text { (Rakhi/Narali } \\
\text { Pournima) } \\
\text { Bail Pola } \\
\text { Ganesha Chaturthi }\end{array}$} & \multirow{2}{*}{$\begin{array}{l}\text { Madhura (Sweet) } \\
\text { Amla (Sour) } \\
\text { Lavana }(\text { Salt })\end{array}$} \\
\hline & Bhadrapada & $\begin{array}{l}\text { Mid August- } \\
\text { Mid } \\
\text { September }\end{array}$ & & \\
\hline
\end{tabular}




\begin{tabular}{|c|c|c|c|c|}
\hline \multirow[t]{2}{*}{$\begin{array}{l}\text { Sharada } \\
\text { (Autumn) }\end{array}$} & Ashvina & $\begin{array}{l}\text { Mid } \\
\text { September- } \\
\text { Mid October }\end{array}$ & \multirow{2}{*}{$\begin{array}{l}\text { Pitra Paksha } \\
\text { Navaratri } \\
\text { Dassera } \\
\text { Diwali } \\
\text { Kojagiri Pournima }\end{array}$} & \multirow{2}{*}{$\begin{array}{l}\text { Madhura (Sweet) } \\
\text { Tikta (Bitter) } \\
\text { Kashaya } \\
\text { (Astringent }\end{array}$} \\
\hline & Kartika & $\begin{array}{l}\text { Mid } \\
\text { October-Mid } \\
\text { November }\end{array}$ & & \\
\hline \multirow[t]{2}{*}{$\begin{array}{l}\text { Hemanta } \\
\text { (Early } \\
\text { winter) }\end{array}$} & Margashirsha & $\begin{array}{l}\text { Mid } \\
\text { November- } \\
\text { Mid } \\
\text { December }\end{array}$ & $\begin{array}{l}\text { Geeta Jayanti } \\
\text { Makara Sankranti }\end{array}$ & \multirow[t]{2}{*}{$\begin{array}{l}\text { Madhura (Sweet) } \\
\text { Amla (Sour) } \\
\text { Lavana (Salt) }\end{array}$} \\
\hline & Pausha & $\begin{array}{l}\text { Mid } \\
\text { December- } \\
\text { Mid January }\end{array}$ & & \\
\hline
\end{tabular}

Shishira ritu means extreme winter season and comes in Magha and Phalguna months of Hindu calendar. Magha is between Mid January to Mid February and Phalguna is from Mid February to Mid March. Mahashivaratri, Holi and Ranga Panchami are the festivals which come in this Shishira Ritu. Madhura (sweet), Amla (sour) and Lavana (salt) are the tastes prevalent in Shishira Ritu.

Vasanta Ritu means spring season and consists of two months Chaitra and Vaishakha. Chaitra is from Mid March to Mid April. Vaishakha is from Mid April to Mid May. Gudi Padwa is the festival which comes in Vasanta Ritu. Katu, Tikta and Kashaya rasas are prevalent in Vasanta Ritu.

Grishma Ritu means summer season and has two months Jyestha and Ashadha. Jyeshtha is from Mid May to Mid June. Ashadha is from Mid June to Mid July. Madhura rasa is prevalent in Grishma Ritu.

Varsha Ritu means rainy season. It consists of two months Shravana and Bhadrapada. Shravana is from Mid July to

TABLE NO.2: SHOWING RELATION BETWEEN RITU AND DOSHA

\begin{tabular}{|l|l|l|l|}
\hline Dosha & $\begin{array}{l}\text { Sanchaya } \\
\text { (accumulation) }\end{array}$ & $\begin{array}{l}\text { Prakopa } \\
\text { (aggravation) }\end{array}$ & $\begin{array}{l}\text { Prashamana } \\
\text { (mitigation } \\
\text { normalcy) }\end{array}$ \\
\hline Vata & Grishma & Varsha & Sharada \\
\hline Pitta & Varsha & Sharada & Hemanta \\
\hline Kapha & Shishira & Vasanta & Grishma \\
\hline
\end{tabular}

Mid August and Bhadrapada is from Mid August to Mid September. Nagapanchami, Narali Pournima, Gopalakala, Pola and Ganesha Chaturthi are the festivals which come in Varsha Ritu. Madhura, Amla and Lavana rasas are prevalent in Varsha Ritu.

Sharada Ritu means autumn season Ashwina and Kartika are the two months which come in Sharada Ritu. Ashwina is from Mid September to Mid October and Kartika is from Mid October to Mid November. Navaratri, Dasshera, Kojagiri Pournima and Diwali are the festivals which come in Sharada Ritu. Madhura, Tikta and Kashaya rasas are prevalent in Sharada ritu.

Hemanta Ritu means early winter season .It consists of two months Margashirsha and Pausha. Margashirsha is from Mid November to Mid December and Pausha is from Mid December to Mid January. Gita Jayanti is the festival which comes in Hemanta Ritu. Madhura, Amla and Lavana Rasa are prevalent in Hemanta Ritu. 
According to Hindu calendar first month of New Year is Chaitra. One cycle of season is completed in this month. New Year will be supposed to good atmosphere, status of body strength, status of Doshas in the body and festivals.

VASANTA RITU (SPRING SEASON) HINDU MONTHS: Chaitra, Vaishakha. ENGLISH MONTHS: Mid March- Mid April, Mid April-Mid May.

STATUS OF ATMOSPHERE: Ruksha (Dryness) .

STATUS OF DOSHAS: Aggravation of Kapha Dosha, Alleviation of Vata Dosha. STRENGTH OF PERSON: Medium.

\section{SHAMAN KARMA (PALLIATIVE} THERAPY): Deepana (Carminative), Pachana (Digestive) .

SHODHANA KARMA

(ELIMINATION THERAPY) : Vamana (Emesis) .

Accumulated Kapha in Hemant Ritu gets liquified because of hot Sunrays from Vasanta Ritu which leads loss of fire and so Kaphaja diseases can occur in this season.

DO'S:

DIET- Barley (Hordeum vulgare L), Wheat (Triticum spp.), Madhu (Honey) and meat of Jangala (dry, arid land) animals and birds should be partaken. Grains likeJawara (Sorghum Bicolor), Bajra (Pennisetum glaucum Corn), Pulses like Green gram (Phaseolus aureus), Brown skinned lentil (Lens Culinaris), Pigeon pea (Pisum Sativum), Chick pea (Cicer Arietinumb), Carrot (Daucus carota), Snake Gourd (Trichosanthes cucumerina), Mustard (Brassica juncea), Fenugreek leaf (Trigonella fornumgraecum), Spinach (Spinacia oleracea), Coriander (Coriandrum sativum) and Ginger (Zingiber officinale Roscoe) should be partaken.

MEDICINE-Rasayana (rejuvinative) drugs and Haritaki (Terminalia chebula) powder with Honey. Exercise, Medicated powder massage over the body, Med icated smoke inhalation, Gargling,
Application of concentrated Collyrium, Concentrated Nasya (nasal administration of medicine) and Application of paste of Sandal (Santalum album) and Agaru (Aquilaria agollocha Roxb.) powder should be done.

LIFESTYLE-One should move along river side to get cold, fragrant breeze of air. One should get up early in the morning before sunrise and do Yoga after elimination of Urine and Stool.

\section{DON'TS:}

DIET-New grains, cold, unctuous, sour and salty food, curd, Black gram (Vigna Mungo), Potato (Solanum tuberosum L.), Onion (Allium cepa L.), Sugarcane (Saccharum officinarum), new Jaggery, Buffalo milk and water chest nut (Trapa natans $L$.) .

LIFESTYLE-Sleeping in day time, and consuming sweet, oily and heavy to digest food.

\section{FESTIVALS OF VASANTA RUTU:}

In the month of Chaitra "Gudhipaadwaa" is celebrated as the first day of Hindu New Year. On this day a pole named Gudhi is erected in front of the house. A new cloth is tied on the Gudhi; a metal vessel is put on to it. Mixture of Neem (Azadirachta Indica) leaves, Guda (Jaggery) and Cumin (Cuminum cyminum) can be used to eat on this special day. (4)

In Ayurveda, properties of Neem leaves and Jaggery have been very well explained. The leaves, flowers, stem of Neem tree are useful as medicine. Cumin is carminative, digestive and useful in Urinary disorders. (5)

In the spring season increased heat of the body subside by bathing with water with Neem leaves to prevent skin diseases like eczema which is custom. (6)

'Akshaya Trutiya' is the second festival celebrated in this season in the month of Vaishakha. The word "Akshaya" means the never diminishing in Sanskrit and the day is believed to bring good luck and success. It is believed that if you do charity on this 
day you will be blessed. It is observed that on Akshay Tritiya, worship of Mrutika (soil/earth) was custom. (7) So on this day earthen pots are offered to the needy as charity. (8)

According to Ayurveda, during these days atmosphere becomes hot. So one gets frequently thirsty. That is why everyone is needed to drink cold water so the idea of earthen pot charity was implemented ..But in ancient time earthen pots were used to keep water cool.

\section{GRISHMA RUTU (SUMMER SEASON) . \\ HINDU MONTHS: Jyestha- Ashadha. ENGLISH MONTHS: Mid May- Mid June, Mid June- Mid July. STATUS OF} ATMOSPHERE: Very Dry.

STATUS OF DOSHAS: Accumulation of Vata and alleviation of Kapha

STRENGTH OF PERSON: Less strength.

SHAMANA KARMA (PALLIATIVE THERAPY) : Vataghna medicine.

SHODHANA KARMA (ELIMINATION THERAPY) :

In this season sun takes away moisture from the atmosphere and air becomes very dry. During this season; trees, animals and birds get affected with severe heat. Water from the river gets absorbed. Everywhere dryness can be seen.

\section{DO'S:}

DIET-Sweet, oily and cold food .Drink liquids like milk, Lassi and Buttermilk.Drinkfruit juices likePomegranate, Lemon, Sugarcane, Watermelon, Muskmelons, Coconut water and Cumin. Drink water in Brahma Muhurta (early in the morning i.e .before sunrise) .

MEDICINE-Sweet and cold mantha (cold infusion), meat soup of Jangala (dry, arid) animal \& birds, ghee, milk, rice should be partaken and increase the strength of a person..Intake of Madya (alcohol) with mixed water according to constitution and strength of the body.

LIFESTYLE-Move in gardens, Bathing twice in a day.

\section{DON'TS:}

DIET-Hot, spicy, dry, salty food, meat and fried items .Food items prepared from Maida (flour of Listea glutinosa) or Besan (flour of Cicer Arietinumb), Intake of wine and pungent, sour and salty taste .

LIFESTYLE-Sunrays, exercise and exhaustion should be avoided. Wearing synthetic clothes and visiting contaminated water and place like fair should be avoided. Sexual intercourse should be avoided.

\section{FESTIVALS OF GRISHMA RITU.}

On the full moon day of the month of Jyeshtha, Vata Pournima is celebrated in this season. On this day women worship Vata (Banyan) tree and seek blessings for their husbands for long and healthy life. (9)

Vata (Banyan- Ficus Bengalensis) is considered as a holy tree. It is a huge tree with strong roots and long life. Vata Pournima is celebrated according to Hindu mythology. On this day Savitri was successful in bringing her husband Satyawaana from the web of death under this tree. So from this day, Vata Pournima is celebrated by women for their husband's long ivity.

$$
\text { According to Ayurveda, }
$$

Panchaanga (five parts) of this tree is used as medicine. $11 \%$ tannin is seen in its twaka (skin/outer surface) . It is cold in potency acts as Graahi (constipative), Mutrasangrahaniya (urine retention) and Vrana ropaniya (heals the wound). Because of its cold potency people used to come under this tree to take rest. Its taste is astringent so it acts as Raktastambhak (Haemostatic) . Sticky substance of leaves is used in the symptoms of Scorpio poison. Hot paste of its leaves can be applied on Arthritis. (10) 
VARSHA RUTU- RAINY SEASON.

HINDU MONTHS- Shravana, Bhadrapada

ENGLISH MONTHS- Mid July to Mid August and Mid August to Mid September STATUS OF DOSHAS IN THE BODYAccumulation of pitta and Alleviation of vata.

PROPERTIES OF ATMOSPHERESnigdha (Unctuous)

STRENGTH OF PERSON-Less strength

\section{SHODHAN KARMA (ELIMINATION}

THERAPY) - Emesis, Purgation, Medicated Enema

During period of Adankala strength and Agni (digestive fire) becomes weak. In Varsha Rutu, weak digestive power is further deteriorated as dark clouds gorged with water blanket the horizon, the wind blows with water droplets causing the vapours rising from the earth generate amlavipaka. Thus the turbid water even the weak digestive fires are all responsible for vitiating doshas.

Thus, in this season when the doshas vitiate reciprocally, it is advisable to adopt regimen that does not vitiate doshas and those that increase digestion.

\section{DO'S:}

DIET-Old cereals, seasoned meat soup and meat of Jangala (dry, arid land) animals, soup of Green grams (Phaseolus aureus), old wine, sour, salty and oily food, old rice and Barley should be consumed. Ghee and Milk during meal should be taken. Bajra (Pennisetum glaucum) or corn (Zea mays var. everta.) with buttermilk should be consumed. Vegetables likered pumpkin (Cucurbita maxima), Brinjal (Solanum melongena), Snake gourd (Trichosanthes cucumerina), Bitter gourd (Momordica charantia) and Bottle gourd (Lagenaria siceraria) should be consumed.Ginger (Zingiber officinale Roscoe), Fenugreek leaf (Trigonellafornum-graecum), Garlic (Allium sativum) and clean water to drink should be used. Boiled water is best. Water from well, pond and river can be used for drinking after mixing Alum. After getting wet in rain bath with clean water is necessary.

MEDICINE-Arishtas (alcoholic bevarages) should be used as medicine. Mastu (Whey) mixed with Souvarchala (Sochal salt-unaqua sodium chloride) or Panchakola powder which contains five ingredients- Pippali (Piper longum), Pippalimula (root of Pipper longum), Chavya (piper brachystachyum), Chitraka (Plumbago zylanica), Nagara (Zingiber officinale) should be used as medicine.

DON'TS:

DIET-Rice (Oryza sativa L.), Potato (Solanumtuberosum L.), ladies finger (Abelmoschus esculentus), heavy food and steal food should be avoided. Well, pond and river water should be avoided. Curd, fish, meat, liquid food and wine should be avoided.

LIFESTYLE-Walking without footwear should be avoided. Body should be scented with perfumes. Clothes should be scented with fumigated drugs. Preferably stay in upper floor of a building free from moisture, cold and mist. Avoid river water. Sleeping during day time and sleeping in open space should be avoided. Exertion, exercise and sun bath should be avoided.

\section{FESTIVALS OF VARSHA RITU}

"Naga Panchami" is the first festival of this season. On this day, farmers and women or people worship snake by offering milk to them. Snake is considered as farmer's friend. Snake prevents destruction of crops from the rats by killing them. To preserve the greenery and to show the gratitude to them people worship snake with wholeheartedly on this day.

According to Ayurveda, skin of snake is used for dhupana chikitsa (fumigation by medicinal plant) in piles and difficulty in delivering baby in women. In ascites, bite of snake opens the 
blockages of channels so that distention of abdomen can be subsided.

Second festival of this season is "Gokulashtami" or "Gopalakala". This day is considered as a birthday of Lord Krishna. People eat curd specially on this day because of belief that Lord Krishna in his childhood used to play with his friends and after playing they used to eat curd and butter always.

According to Ayurveda, sour and sweet taste is advisable for decreasing vata because taste of curd is sour and vipaka of curd is also sour.

Third festival of this season is "Shravana Pournima". Shravana Pournima is also known as "Rakhi Pournima" or "Narali Pournima". This festival is celebrated in this month on the day of full moon. On this day sisters tie Rakhi made of threads on the wrists of their brothers for their long and happy life and their brothers vow to take care and protect their sisters. This is the festival of celebrating the bond of love between a brother and sister. On this day special Narali bhat (coconut rice) is prepared in every house.

During the rainy season, the sea is ferociously restless so, the fishermen celebrate Narali Pournima to calm the sea by offering the auspicious coconut fruit.

According to Ayurveda, Coconut (Cocos nucifera) is called as Mahavruksha or Kalpavruksha because it has multiple uses in kitchen and medicine also. Coconut oil is used in cooking and medicine. Coconut is having sweet taste, aphrodisiac, gives strength, makes stout and cleans the urinary bladder. Coconut water is cold in potency, relieves thirst and increases urine and decreases fever. Oil of it is used as tonic for hair and act as good wound healer. Wine prepared from it is used to subside burning sensation, gives strength and cleanses bladder. Root of it is astringent in taste, used in urinary calculus, diabetes and menorrhagia. By burning hard cover of it, we get oil which is good to cure skin diseases. Milk of coconut acts as tonic to weak person and after the surgery. (11) To show gratitude to it, coconut is worshipped by people on this day.

In the month of Bhadrapada on the Amavasya (darkest moonless night) after the rainy season "Bail Pola" is celebrated. This is another festival of farmer. In the life of farmer Bail (Ox) is has most important place. After the agricultural work done by ox during rainy season farmer shows gratitude towards ox on this day and so farmers worship ox on this day.

'Ganesh Chaturthi' is celebrated on fourth day of Shukla paksha in the month of Bhadrapada, during rainy season. This day is considered as birthday of Lord Ganesha. And on Ananta Chaturdashi (eleventh day after Ganesha Chaturthi) the idol of Ganesha is drowned in to the pond (visarjana) . Ganesha word is derived from two words; one is Gana which means group and second is Isha which means leader. So, Ganesha is supposed to be leader of one group.

According to Ayurveda or in Sanskrit grammer root word of Gana is derived from guna. Guna means qualities which are Satva, Raja and Tama. Ganesha means the controller of the three qualities. So, Ganesha is considered as God of intelligence and quality. To worship lord Ganesha people offer twenty one durva (Cynodon dactylon) to him.

During the month of Bhadrapada, durva grows rapidly and it absorbs heat of the body. In this particular month or season, pitta gets accumulated in the body and so Durva makes its strength low. (12)

In Ayurveda, Durva is described as medicine. Durva is said to have many medicinal properties and health benefits including antimicrobial and antiviral properties. Recent research at university of Allahabad in India has shown the glycemic potential of cynodon dactylon extract has significant hypoglycaemic as well as antidiabetic effects. (13) 


\begin{abstract}
SHARADA RUTU (AUTUMN SEASON)

HINDU MONTHS- Ashwina, Kartika ENGLISH MONTHS- Mid SeptemberMid October, Mid October- Mid November
\end{abstract}

STATUS OF DOSHAS IN THE BODYAccumulation of pitta

PROPERTIES OF ATMOSPHEREUnctuous.

STRENGTH OF PERSON: Medium Strength.

\section{SHODHANA}

KARMA

(ELIMINATION

Virechana (Purgation) .

In Varsha Ritu, the body is accustomed to the cold atmosphere and hence pitta is accumulated but fails to aggravate Kapha due to frigid atmosphere when the sunrays become hot in the ensuring Sharada ritu, the body becomes suddenly hot and by this, the accumulated pitta aggravates.

In this season digestive fire increases. Water heated by besieged rays of sun during day time and cooled by moon rays at night detoxified by the star Agastya (the star anapus) rising in this season and is pure and clear, capable of pacifying tridoshas which is neither abhishyandi (secretory) nor ruksha (causing dehydration). It is as good as divine elixir and known as Hamsodaka . (Hamsodaka word derived from two words: Hamsa: Swan, Udaka: Water.Sun and Moon are considered as Hamsa (Swan) .) Purified water by the rays of sun and moon or the water which can be capable to drink by swan is Hamsodaka. Swan always drinks clean water. Water which can be drink which is purified by rays of sun and moon. (14)

DO'S:

DIET- Sweet, light, cold and pungent taste diet, rice (Oryza sativa L.),), barley (Hordeum vulgare L.) .
Drink clean water or alum mixed with water. Vegetables like Bitter gourd (Momordica charantia), snake gourd (Trichosanthes cucumerina), Fenugeek leaf (Trigonella foenum-graecum), bottle gourd (Lagenaria siceraria), spinach (Spinacia oleracea), Radish (Raphanus sativus), Water chestnut (Trapa natans L.), Carrot (Daucus carota), Cabbage (Brassica oleracea or variants) and grapes (Vitis vinifera), tomato (Solanum lycopersicum), drink fruit juices like lemon (Citrus $\times$ limon) juice and eat dry fruits especially dried grapes and coconut. Eat vegetables without spices. Drink water before sunrise. MEDICINE-

$$
\text { Chyavanaprasha, }
$$

Amalaki

Rasayana, Brahma rasayana etc. can be consumed after the consultation of Doctor. Administration of Tikta Ghrutpana (Bitter Ghee) is good in this season. Eat Triphala churna, Nishottha Churna and Amaltas. Eat green gram and black gram pulses.

\section{LIFESTYLE-}

Perform regular oil massage, regular exercise. Those who are unable to do exercise, they can do morning walk. Do take sleep in room. Wear clean and light clothes. Bath in swimming pool and pond.

\section{DON'TS:}

\section{DIET-}

Food prepared with maida (flour of Listea glotinosa) should not be consumed. Hot, pungent, spicy and oily food, Fatty and salty and sour diet should be avoided. Fish should be avoided. Guava (Psidium guajava) in excess and stem vegetables should be avoided.

Vanaspati Ghee and unripe Cucumber (Cucumis sativus) should be avoided.

\section{LIFESTYLE-}

Sleeping in day time should be avoided. Do not cover mouth while sleeping and not to sleep under sky in open space. 


\section{FESTIVALS OF SHARADA RITU:}

"Pitra paksha" (Cermony of fifteen days to remind the departed ancestors of family) is specially observed by hindu people in the month of Ashvina. The period of the festival extends over the dark fortnight of the month. People celebrate the festival with religious fever. It is celebrated to pacify the souls of deceased ancestors. On each day of the festival, the eldest son of a family performs certain ceremonies. He offers oblations Pinda (rice balls etc.) and water for the departed souls. (15)

In Ayurveda three basic desires are mentioned by the name Pranaeshana, Dhanaeshana

and

Paralokeishaa.Praanaeshana means desire to live long, Dhanaeshana means desire to earn money and Paralokaeshana means desire to get happy life after death . These three desires belong only to such persons as are after enjoyment of happiness in this world and the world beyond. Desire to perform virtuous acts is related to the desire to attain happiness in life after death. While discussing this issue, topic of rebirth is explained. And to get salvation, Pitra paksha is observed.

'Navratri' is celebrated after performing religious act like Pitra Paksha as second festival of this season. Nine holy days in the month of Ashwina are celebrated as Navaratri. This festival is dedicated for goddess which is symbol of women empowerment. To salute women empowerment this festival is celebrated all over India with full of enjoyment. (16) Either on the eighth or ninth day, The ladies of house prepare delicious food offering as Prasada.For nine consecutive days the ladies keep fast. On the festival day they give food to nine girls. It is symbolic act of worshipping the goddess in the virgin form. This is abserved generally in Northen India. (17)

According to Ayurveda, Prakriti and Purusha are the root cause of evolution of universe. Every particle of the universe is made up of triguna (Satva, Raja and Tama) which is originated from Prakriti. In Navaratri power of nine goddesses are worshipped. Among these some are of mild quality which denotes Satva quality and some are of aggressive quality which denotes Raja quality. And we can consider this festival is a symbol of worship of the qualities of triguna.

"Dassehera"is a festival which celebrates the victory of good over evil. It has mythological aspect. It falls on the tenth day in the month of Ashwina. Its other name is "Vijaya Dashmi". The battle between Goddess Durga (Good) and Mahishasura (Evil) were fought for nine days. On the tenth day Durga killed Mahishasura and that is why this tenth day is celebrated as Vijaya Dashmi. This day is also celebrated as the victory of Lord Rama who killed and defeated the powerful ruler of Lanka, the ten headed Ravana during period of Ramayana .

Another mythological story is also behind the celebration of Dassehera during period of Mahabharata. On this day Arjuna had relieved the cows of king Virata from the Shami (Prospsis cineraria) tree where the weapons of battle were kept or hidden.

Above stories had happened in different periods but on the same day of Vijaya Dashmi. So this day is celebrated as the symbol of victory. And people worship Goddess Durga by offering leaves of Shami-Apta (Prodopis spicigera) and instruments also.

According to Ayurveda Shami-Apta (Prodopsis Spicigera) is a holy tree. It alleviates Raktapitta (bleeding disorders) . Ash of skin of this tree is rubbed over particular area to get rid of excess hair, It is Garbhasthaapaka (to establish and maintenance of pregrancy). (18)

"Deepawali/Diwali" falls on the darkest moonless night of Amavasya, the fifteenth day of Krishna paksha in the month of Kartika after Vijayadashami, This festival is celebrated for five days. 
Deepawali or popularly known as Diwali has got great mythological, religious and cultural importance. Dipa in Hindi or Diwaa in Marathi means lamp. Deepawali is the festival of lights. We forget our sorrows and a bit in the light. Light is the symbol of act of fulfillment and mysteries. During this period we get the yields from the farms. Rains are over and atmosphere becomes pleasantly cool. For the farmer crops is their wealth so they get reason to celebrate their happiness in the form of festivals like Diwali, Vasubarasa, Dhanatrayodashi, Naraka Chaturdashi, Bali Pratipada and Bhaubeej and these are six events which are celebrated during Diwali. During these six events people wake up early in the morning and bath with oil massage and application of scented powder all over the body.

In Ayurveda benefit of bath, oil massage is very well explained. But especially people perform this act during this season or festival because of coldness or winter season. Due to coldness, vata aggravation can be subsided by oil massaging and luke warm water. Scented powder is the combination of different medicinal drugs which are helpful to destroy bad odour of sweat and it also improves the skin complexion.

"Vasubaaras" is the first day of Diwaali. Vasu Baras or Bagh Baras (Vagh Baras) or Govatsa Dwadashi is the twelfth the light of day of the Krishna Paksha of Ashwina calendar month which is dedicated to the cow and calves. In hindi language Govatsa derived from two words Go and vatsa where as Go or Vasu means 'cow' and 'vatsa' means calf.

Indian people exceptionally inside rural areas symbolically think that the cow represents motherhood. In urban India cow is the individual economic source of thousands of families. Hence married women worship them.Images of cow and calf are decorated with turmeric (Curcuma longa) and kumkum (Crocus sativus)
On this day people worship cow which is definitely an auspicious thing which gives milk and is the symbol of wealth.

Ayurveda has described qualities of milk and specially cow's milk and so people show the gratitude to cow and calf by worshipping them.

"Dhantrayodashi" is the second day of Diwali. It is al also known as Dhana Terasa. Dhana means "wealth" and Trayodashi means "13th day"It is also celebrated as birthday of Lord Dhanvantari who propagated the science of Ayurveda. Dhanvantari is an Avatar (incarnation) of lord Vishnu from the hindu tradition. He appears in the Vedas and Puranas as the physician of the god and the God of Ayurvedic medicine. It is common practice in hinduism for worshipers to pray to Dhanvantari seeking his blessings for sound health for themselves and/or others especially on Dhanterasa .Due to this science life of human being becomes healthier in the country by worshipping Lord Dhanvantari. So his birthday is celebrated by the practitioners of Ayurveda every year on Dhanterasa, There are many legends revealing different stories about this day. One legend says when gods and demons churned the ocean to get nectar, Dhanvantari emerged carrying a jar of the elixir from it. (19)

On this day Coriander seeds are worshipped by people. During this season coriander grows more. And to prevent the aggravation of Pitta people drink water of Coriander with Khadi sakhara (sugar cubes) which mitigate Pitta.

Ashwina Krishna Chaturdashi means "Naraka Chaturdashi". This day is fourteenth day of the month of Ashwina considered as the victory on demon Naraka sura who was killed by Lord Krishna.Broadly this signifies the victory of good over evil. On this day people take bath before sunrise and cleans houses, lights lamps then they crushed the bitter 
fruit called Karita (cucumis melo var agrestis) by first toeof right leg which represents the head of demon king Narakasura . (20) and then the entire family sits down for a joint breakfast of savouries called Farala (sweet preparations) .

Fifteenth day in the month of Ashwina is no moon day and so it is darkest and celebrated as "Laxmi Pujana "after Naraka Chaturdashi . This ritual is made on the dark day because after every black night bright light will destroy the darkness. So after the darkest moon night, Goddess Laxmi who is the symbol of cleanliness, beauty, light and wealth is worshipped. This is considered as an auspicious day for women. Lakshmi Puja or the worship of the goddess of wealth is the main event on Diwali in North and West India. It is popularly believed that Lakshmi likes cleanliness and will visit the cleanest house first. Hence broom is worshiped with offerings of turmeric (Curcuma longa) and kumkum (Crocus sativus) on this day. Lamps are lit in the evening to welcome the goddess as they are believed to light up her path. On this day, a supported light of knowledge is said to dawn upon humanity. This selfenlightenment is expressed through the twinkling lamps that illuminate the abode of the worshippers. It is believed that on this day, the goddess walks through the green fields and loiters through the bylanes and showers her blessings on mankind for glory and prosperity. (21)

Marigold (Calendula officinalis) (22) flowers are offered to Goddess Laxmi.Marigold is grown mainly in March and April and is known to grow rapidly. They are known to be a rich source of flavonoids and vitamin $\mathrm{C}$. They have no fat content and therefore aid weight loss. It is used in the treatment of minor burns when used in the form of ointments or a tincture. Marigold has anti-inflammatory properties. In the treatment of allergic reactions, eczema and bruising it is being used. In the treatment for plantar lesions that tend to occur on the feetmarigold is useful. Health benefits and therapeutic uses of marigold flowers as well as the leaves of the marigold is very well explained .It is beneficial in minimizing the number of tumors in the case of breast cancer as well as in the prevention of the development of new cancer cells. Besides breast cancer, Marigolds are also known to be effective against colon, leukemia and melanoma cancer cells, effective against painful mouth and stomach ulcers as well as colitis. The petals of the marigold flowers are also used in sitz baths as they are effective in healing vaginal infections, bladder infections, healing of stitches post child birth as well as haemorrhoids. To prepare a sitz bath the petals of the marigold flowers should be boiled for some time and then added to the warm bath water. (23)

"Bali Pratipadā" is the fifth day of Deepavali (Diwali), the Hindu festival of lights. It is celebrated in honour of the notional return of the Daitya (demon) king Bali to earth. Bali Pratipadai falls in the Gregorian calendar months OctoberNovember. It is the first day of the Hindu month Kartika and is the first day of the bright lunar fortnight (day after new moon day) in the month. It is also called the Akashadipa (lights of the sky). It is celebrated as the first day of the Vikram Samvat calendar in Western India.

According to Hindu mythology, Bali Pratipadacommemorates the victory of godVishnu in his dwarf incarnation i.e Vamana, the fifth incarnation of theDashavatara (ten major incarnations of Vishnu) defeating Bali and pushing him to the nether world. But Bali was bestowed a boon by Vishnu that on this day he (Bali) be honoured and people celebrate his devotion and noble deeds to his people . (24)

This is first day of the month of Kartika which is symbol of love and affection. In Maharashtra it is celebrated 
as Padva or Bali Pratipada. The day is linked to worship of king Bali. On this day wife prays for long and healthy life for her husband. To enhance the bond of love between the married couples they exchange gifts .

Sixth day of Diwali is "Bhaubeeja”. The celebrations of this day are similar to the festival of Raksha Bandhana. On this day sisters pray for a long and happy life for their brothers by performing the Aukshana (Tika) ceremony. On this day in contrast to Raksha Bandhana sisters present gifts to their brothers. According to a popular legend in Hindu mythology after slaying the evil demon Narkasura, Lord Krishna visited his sister Subhadra who gave him a warm welcome with sweets and flowers. She also affectionately applied tilak on Krishna's forehead. Some believe this to be the origin of the festival.This day is celebrated by brothers and sisters. By wearing clean and new clothes with ornaments sister does Aukshana (Aukshana means the ceremony in which wet kumkum is applied on forehead of brother in vertical line and the plate with small lamp and sweets is rotated from left to right by sister for five times. The lamp is the symbol of light which destroys the darkness) to her beloved brother and this is done to protect the brother from the darkness which is the symbol of bad things and to increase the longevity and healthy life. To add charm to the occasion, of Bhau beeja gifts are exchanged between brothers and sisters as a token of love and appreciation.

So in short, Diwali is the festival of love, affection and lights .It enhances the relationship between the family members and the community as whole.

The full moon day of Ashwina is called the "Kojagari Pournima". The Sharada Purnima or Kojagari Purnima or Kumar Purnima is a harvest festival celebrated on the full moon day of the Hindu lunar month of
Ashvina (September-October) . It marks the end of monsoon. There is a traditional celebration of the moon and is also called the 'Kaumudi celebration', Kaumudi means moonlight.

This event is celebrated by observing sacred Kojagiri Pournima vrata for Goddess Laxmi and Lord Indra. To welcome her houses, temples and streets etc. are illuminated. A light is lit outside one's house to let Goddess Laxmi, the Harbinger of wealth and prosperity while going on her rounds to overlook and pause to boost her blessings. Some people believed that on this night Goddess Laxmi visits every house asking, "Ko Jaagarati?" means "Who is awake?" and shows her pleasure on those she finds awake. Hence the night is spent in festivity and various games of amusement in honour of the goddess. So people sit in the moonlight singing songs or keep themselves entertained in some other way. They observed fast and take only fluids like coconut water or milk. Milk is boiled till it thickens and a mixture of dry fruits is added to it and offered as delicacy. There is also a tradition to have milk with rice flakes on this night. It is a harvest festival and is celebrated throughout the country, particularly by Maharashtrians. (25)

In Ayurveda, in this season moonlight is enjoyed atop terrace of white mensions and moonlight gives maximum strenghth and cooling effect to the body, Moonlight detoxified by the star Agastya (the star canopus) rising in this season and is pure and clean.So milk drink at this moonlight gives maximum strength. Milk is included in Kshira varga which is sweet in taste, purgative and mitigates Pitta. Boiled milk is to be made cold in the presence of moonlight. This milk is good for drinking. Almond, Cashew nuts are added to this drink which makes it tasty as well as nutritious which is the need of this season. (26) So people gather on this night and drink milk with almond and cashew nuts. 
HEMANTA RITU (EARLY WINTER)

ENGLISH MONTHS-Margasheersha, Pausha

ENGLISH MONTHS- Mid November-

Mid December

Mid December- Mid January

STATUS OF DOSHAS IN THE BODY -

Aggravation of pitta and alleviation of vata

PROPERTIES OF ATMOSPHERESCold

STRENGTH OF PERSON- Highest strength

\section{SHODHANA THERAPY}

(ELIMINATION THERAPY) - Basti

(Medicated Enema)

In Hemanta Ritu due to the cold breeze the body temperature is obstructed and enters deep into the body and increases digestive fire in the strong persons and is able to digest hard food substance also. (27)

DO'S:

DIET-Unctuous, sweet, heavy meals should be consumed. Oil, ghee and hot meal should be consumed. Nutritious Laddoo (ball-shaped sweets) and modaka (sweet rice dumpling) should be consumed. New Shali should be consumed. Dry fruits should be consumed. LIFESTYLE-Bath with oil massage should be done. Application of dry powder all over the body should be done. Woolen and dark colored clothes are to be worn. One should wear socks and shoes. One should use lukewarm water to wash hands and legs.

MEDICINE-Ashwagandha Paka, Methi Ladoo, Chyavanprasha and Brahma Rasayana should be consumed.

DON'TS:

DIET-Cold drinks should be avoided. One should consumed less food and watery food.

LIFESTYLE-Sleep in day time should be avoided. One should not stay in the place where wind blows. One should wear cotton and light clothes.

FESTIVALS OF HEMANTA RITU :
The "Gita Jayanti "or the day when Gita (A sacred book on ethics) was revealed to the world is celebrated traditionally on the eleventh day of the Shukla Paksha (bright half) in the month of Margasheersha. The pious Gita is a composition of the thoughts exchanged between Krishna and Arjuna, just before the Mahabharata war. Later it was integrated in Mahabharata by Veda Vyasa. It is composed of more than one hundred thousand shlokas.

On Gita jayanti special Puja (rituals) and rendition of the Bhagvad Gita is performed. People prey to Lord Krishna to shower his grace on all his devotees. (28)

In Ayurveda, causes of all diseases are very well explained. Bhagvad Gita is a holy book which gives the wise words to live strong and peaceful life.Ayurveda also described 10 sins which should not be committed by the body, the gab or the mind.

(1) Himsa (violence),

(2) Steya (theft),

(3) Anyatha Kama (infidelity),

(4) Paishunya (tale bearing),

(5) Parusha (abuse/being rude),

(6) Anrut (speaking untruth/lying),

(7) Sasmbhinalpa (uttering rubbish),

(8) Vyapada (tendency to harm),

(9) Abhidya (longing for other's belongings) and

(10) Drgviparyaya (atheism) . (29)

The only festival which falls on the same day every year is "Makara Sankranti". It is celebrated on January 15, Shukla Paksha in the month of Pausha. Makara literally means "Capricorn" and "Sankranti" is the day when the sun passes from one sign of the zodiac to the next.

Although geographicallyon this day sun passes from the Tropic of Cancer to the Tropic of Capricorn. That is the sun enters the constellation of Makara (Crocodile) and begins to move towards 
the north. This day has a very special significance because the day and the night of Makara Sankranti are of equal hours.

The people of India celebrate the day by eating "Khichadi" prepared by mixing rice and Dal. On the feast of Makar Sankranti Tila (Sesamum orientale Linn.) eating is considered as auspicious. The Tila ladoo is prepared which has nutritive and medicinal properties. Women celebrate this day by applying Haldi (turmeric) - Kumkum on each other's forehead. Children make this day even more colorful by flying kites. During this season Bajra (Pennisetum glaucum) grows more which is hot in potency. During this season Brinjal (Solanum melongena) also grows more so in vegetable markets these can be easily available. On thisday special meal is prepared i.e. Bajra roti with Tila along with brinjal vegetable.

During this season people offer Tilagula i.e. Tila (seasame) and Jaggery to each other. Tila is hot inpotency. Makar Sankranti is a festival in which people forget disputes to celebrate festival by offering sweets.

\section{SHISHIRA RITU (EXTREME WINTER)}

HINDU MONTHS- Magha, Phalguna ENGLISH MONTHS- Mid January- Mid February

Mid February- Mid March

STATUS OF DOSHAS IN THE BODY Accumulation of kapha,

Mitigation of vata.

\section{PROPERTIES OF ATMOSPHERES-} Dry

STRENGTH OF PERSON- Highest Strength

SHAMANA KARMA (PALLIATIVE THERAPY) - Deepana (Carminative), Pachana (Digestive)

The intensity of cold increases during this season. Moreover, Roukshya property (dryness), so characteristic of Adanakala is also present in this season.
DO'S:

DIET-Heavy food, milk should be consumed.

LIFESTYLE-Oil massage should be performed. Atapsevan a (exposure to sunlight) should be done. One should preferably bath with warm water. One should wear warm and dark colored clothes, socks and shoes. One should stay in places where heater can be used.

MEDICINE-Haritaki (Terminalia chebula) and Pippali (Piper longum) should be consumed.Ashwagandha (Withania somnifera), Musali (Chlorophytum borivilianum), Badama (Prunus dulcis) and Black gram (Vigna mungo) should be consumed. Methi Laddoo (sweet balls prepared with Trigonella fornum-gracum) should be consumed.

Lohasava,

Ashwagandhaarishta and Drakshasava should be consumed.

DON'TS:

DIET-One should avoid cold drinks and cold food.

One should not keep feet open. One should not wear light and white clothes. One should eat less food.

LIFESTYLE-One should avoid cold breeze.

\section{FESTIVALS OF SHISHIRA RUTU:}

Maha Shivaraatri, Holi and Ranga

Panchami are the three festivals celebrated during this season. "Maha Shivaratri" is celebrated during the month of Phalguna. The festival is principally celebrated by offerings of Bela or Bilva (Aegel marmelos) leaves to Shiva, keeping all-day fasting and jagarana (all-nightvigil). All through the day devotees chant "Om Namah Shivaya", the sacred mantra of Lord Shiva. Penances are performed in order to gain boons in the practice of Yoga and meditation in order to reach life's highest good steadily and swiftly. On this day the planetary positions in the Northern hemisphere act as potent catalysts to help a person raise his or her 
spiritual energy more easily. The benefits of powerful ancient Sanskrit mantras such as Maha Mrityunjaya Mantra increase greatly on this night.

On this day Lord Shiva and his wife Parvati are worshipped by young girls and even men, in the hope of getting a perfect mate for themselves. They offer Lotus flowers and Bilva (Aegel marmelos) leaves. (30)

According to Ayurveda, till this day the coldness in the atmosphere becomes less and people start feeling the increasing heat in the atmosphere. Worms and flatus decrease by the use of Bilva leaves. Soaking Bilva leaves in water overnight and then using it internally will subside the diseases of abdomen. Kapittha (Limonia acidissima) is also easily available during this period. Kapittha alleviates Pitta. So people should eat chutney (paste) of Kapittha with Jaggery. (31)

"Holi and Ranga Panchami" are the second festival of this season. This festival is celebrated from Pournima (Full Moon Day) to fifth day of Phalguna month. Holi is a spring festival also known as the festival of colours or the festival of love Holi celebrations start with a Holika bonfire on the night before Holi where people gather, sing and dance. The next morning is a free-for-all carnival of colours where participants play, chase and colour each other with dry powder and coloured water with some carrying water guns and coloured water-filled balloons for their water fight. Traditionally washable natural plant-derived colours such as turmeric (Curcumalonga), neem

(Azadirachta indica), kumkum (Crocus sativus) were used; but waterbased commercial pigments are increasingly used. The festival signifies the victory of good over evil, the arrival of spring and end of winter. This is a festive day to meet everyone, play and laugh together, forget and forgive and repair ruptured relationships.So, Ranga
Panchami is celebrated by applying different colors to each other. (32)

According to Ayurveda, leaves fall off, arrival of new leaves can be seen. Every human being can adopt this change. This is the example or a learning lesson to people that forget all sorrows, clashes and live life happily. This festival is the symbol of happy life is ahead in coming year, be ready for enjoying it.

\section{Observations:}

The New Year is celebrated by erecting a pole by the name Gudhi in front of the house. Just like the end of the year is celebrated by Rangapanchami.

After minute observations, all these festivals stand around either on the full moon day or dark moonless night. It means that festivals are depend on changes in atmospheres and the status of doshas in the body.

Every festival is celebrated by availability of leaves, flowers and vegetables in surrounding area. So that it is very important to follow the rules of Rutu Sandhi according to Ayurveda. The last seven days of a season are included in Rutu Sandhi. In this period, one should taper the regimens of the previous season and practice those of the next season in a gradually phased manner. Immediate abandoning and adoption of regimens will cause various diseases due to improper adaption. (33)

While celebrating any festival people should consider the atmosphere of that particular area or country and adopt diet and seasonal regimen accordingly.Not to follow the diet and seasonal regimen only on the basis of month and religion. It can be harmful to the health of the person. For example Diwali is celebrated in Sharada ritu (Autumn season) in India where digestive fire is good but in Ausralia during this period sunrays are more hot so tremendous summer can be seen and also digestive fire will decrease. If person celebrated Diwali festival in Ausralia by 
eating oily food which can not be digested properly and can lead various diseases. Same period in India Diwali celebration gives happiness and same period in Ausralia Diwali celebration can lead diseases.

\section{Conclusion:}

While celebrating festivals, every person should follow the regimen of Rutu Sandhi according to desha (land) .

Festivals are depends on changes in atmospheres and the status of doshas in the body. Clear the dust of mythological stories from the eyes and religious beliefs to celebrate the festivals and accept the good things which are good for the health.

\section{References:}

1. Sreekumar T. Ashtanga Hridaya Vaghabhata Sutrasthan-1A. H. Su.3/4, 3ed Kerala, Harisree Hospital, 2011January, 83p

2. Sreekumar T. Ashtanga Hridaya Vaghabhata Sutrasthan-1A. H. Su.3/4, 3ed Kerala, Harisree Hospital, 2011January, 82p

1. T. Sreekumar Ashtanga Hridaya Vaghabhata Sutrasthan-1 A.H. Su.3/4, 3ed Kerala, Harisree Hospital, 2011January, 83p

2. Shyam Dua Famous Great Indian Festivals, 1ed, Delhi, Tiny tot Publication 2004, 35p

3. K.C. Chunekar Bhav Prakash Nighantu, Haritakyadi Varga 84-85 Reprint Varanasi Choukhamba Vishwabharati, 2004, 31p

4. Swati Karve Bharatiya San aani Utsav, 1 ed, Pune Utkarsha Prakashan

5. $2008,17 \mathrm{p}$

6. 7.http://en.wikipedia.org/wiki/Aksha ya_Tritiya

7. 8. Shree Sanjay Deshpande Aapale San 1ed Pune Aadarsh Vidyarthi Prakashan, 2010,

8. $4 p$
9. 9. Shree Sanjay Deshpande Aapale San 1ed Pune Aadarsh Vidyarthi Prakashan,,, 2010, 5p

10. 10. K.C. Chunekar Bhav Prakash Nighantu, Vatadi Varga 1-2 Reprint Varanasi Choukhamba Vishwabharati, 2004, 513p

11. 11. K.C. Chunekar Bhav Prakash Nighantu Amradi Phala Varga 41-42 Reprint Varanasi Choukhamba Vishwabharati, 2004, 559p

12. 12. Mrs. Swati Karve Bharatiya San aani Utsav, 1ed, Pune Utkarsha Prakashan 2008, 64p

13. www.naturalhomeremedies.co/bermu da\%grass accessed on 11/12/2014

14. T. Sreekumar Ashtanga Hridaya Vaghabhata Sutrasthan-1 A. H.Su.3/51-52, 3 ed, Kerala, Harisree Hospital, 2011January, 94p

15. Shyam Dua Famous Great Indian Festivals, 1edDelhi, Tiny tot Publication 2004, 80p

16. Shyam Dua Famous Great Indian Festivals, 1edDelhi, Tiny tot Publication 2004, 71p

17. 17. Shyam Dua Famous Great Indian Festivals, 1edDelhi, Tiny tot Publication 2004, 71p

18. 18. K.C. Chunekar Bhav Prakash Nighantu Vatadi Varga 72-73, Reprint Varanasi Choukhamba Vishwabharati, 2004, 545-546p

19. 19. Shyam Dua Famous Great Indian Festivals, 1edDelhi, Tiny tot Publication 2004, 23p

20. www.astrospeak.com. Accessed on $16 / 03 / 2015$

21. 21www.en.wikipedia.org/wiki/Laxmi _Puja Accessed on 16/03/2015

22. www.ecoindia.com Accessed on $16 / 03 / 2015$

23. http://www.home-remedies-foryou.com/herbs/marigold.html Accessed on 16/03/2015

24. 24..http://en.wikipedia.org/wiki/Balip ratipada Accessed on 16/03/2015

25. http://en.wikipedia.org/wiki/Sharad_ Purnima Accessed on 16/03/2015 
26. Shyam Dua Famous Great Indian Festivals, 1edDelhi, Tiny tot Publication 2004, 23p

27. Vidyanath Ashtanga Hridaya A.H.Su 3/7 1ed, Varanasi Choukhamba Surbharati Prakashana, 2013, 46p

28. Shyam Dua Famous Great Indian Festivals, 1edDelhi, Tiny tot Publication 2004, $31 \mathrm{p}$

29. 29. T. Sreekumar Ashtanga Hridaya Vaghabhata Sutrasthan-1A.HSu.2/2223, 3ed, Kerala, Harisree Hospital, 2011January, 72 p
30. 30. Shyam Dua Famous Great Indian Festivals, 1edDelhi, Tiny tot Publication 2004, 61p

31. Swati Karve Bharatiya San aani Utsav, 1 ed, Pune Utkarsha Prakashan 2008, 133p

32. http://en.wikipedia.org/wiki/Holi Accessed on 16/03/2015

33. 33. T. Sreekumar Ashtanga Hridaya Vaghabhata Sutrasthan-1A.H.Su. 3/58, 3 ed, Kerala, Harisree Hospital, 2011January, 96p 